\title{
Research on the Strategies for Improving the Effectiveness of College English Listening Teaching
}

\author{
Ge Zhang* \\ College of Post and Telecommunication of Wuhan Institute \\ of Technology \\ WIT \\ Wuhan, Hubei, China
}

\author{
Chunying Li \\ College of Post and Telecommunication of Wuhan Institute \\ of Technology \\ WIT \\ Wuhan, Hubei, China
}

\begin{abstract}
The aim of this study was to make students participate actively in class, and improve the effectiveness of aural English teaching. Improving the effectiveness of College English listening teaching is not only the focus of teachers' attention, but also the hope and desire of students. However, for a long time, some unsatisfactory phenomena and problems in traditional aural English teaching have been discussed, including the backward teaching ideas, the monotonous teaching environment, the single teaching methods, and the outdated teaching content and so forth. These problems seriously affect and restrict the quality and efficiency of College English listening teaching. Then strategies are presented on how to teach English listening more effectively: firstly, teachers could change the teaching ideas of aural English; secondly, authentic listening teaching environment could be constructed by presenting environmental clues; thirdly, diversifying the teaching methods of listening could throw the emphasis on integrating listening with other teaching activities; finally, teaching content of listening could be selected appropriately. Recent research had shown that teachers could use creative methods of aural teaching, and make an effort to stimulate students' interest. There is still a long way to go for EFL educators.
\end{abstract}

Keywords—aural English; effectiveness; problems; strategies

\section{INTRODUCTION}

Aural English teaching is a very important part of College English teaching. It not only promotes and complements the reading, writing and speaking of English teaching, but also has a very important positive significance for the cultivation of students' comprehensive quality. However, the present situation of College English listening teaching is not satisfactory. Especially all the participants in English listening class are not satisfied with the current situation. Teachers who are generally tired of facing a group of absent-minded students, playing listening materials, explaining key points and checking answers with students over and over again. Students are also generally tired of boring listening materials, inactive listening teachers, and monotonous learning atmosphere. All abovementioned are caused by the backward teaching ideas, the monotonous teaching environment, the single teaching methods, and outdated teaching content. These problems seriously affect and restrict the original intention of College English listening teaching. Therefore, in order to stimulate students' initiative in learning and improve the effectiveness of College English listening teaching, the paper indicates that teachers need to change the listening teaching ideas, construct the listening teaching environment, diversify the listening teaching methods and select teaching content of listening and so forth.

\section{ChANGing ThE TEACHING IDEAS OF AURAL ENGLISH}

The idea is the guide of action. Advanced, correct and proper teaching ideas can continuously improve the effectiveness of teaching activities. On the contrary, backward, wrong and mechanical teaching ideas can obstruct the development of teaching activities [1]. Therefore, it is important to change and shape the teaching concept of College English listening teaching activities.

\section{A. Highlighting the Guiding Role of Teacher}

At present, in college English listening teaching activities, teachers are used to playing audio and video materials of English listening, then ask students to complete listening exercises accordingly, and finally, teachers check answers with students. It can be found that the status of teachers has not been fully reflected, and their role has not been fully played in the whole English listening teaching activities. Obviously, teachers are in a very embarrassing and dispensable situation. The reason is that the concept of teacher's guiding role has not been implemented in English listening teaching. The teachers' guiding role does not mean that the whole listening teaching activities are mainly dominated by teachers, but refers to giving full play to the teachers' function of organizational leadership, guiding and helping students achieve the goal of English listening teaching with their own special professional knowledge, skills, and methods. In short, before listening, teachers should carefully design English listening teaching, including teaching objectives, teaching difficult points and time allocation and so on. At the while-listening stage, teachers should pay attention to guide, explanation, and discussion. After listening, teachers' main task is to review and reflect on the organization of this listening teaching activity, especially exertion of their own guiding role.

\section{B. Insisting Student-centered Teaching}

Teaching includes teachers' teaching and students' learning. Therefore, we must insist the student's main role if we want to highlight the teacher's guiding role, it is clear that the embodiment of the student's main role is the strong evidence of the teacher's guiding role. However, most people think studentcentered learning refer to students' independent study, selflearning and free learning. For example, when students enter 
into the language lab, some teachers usually assign some tasks to students, and let them do whatever they want to do. Learning is entirely carried out by students according to their own interests and perseverance. In order to change the abovementioned wrong ideas in English listening teaching, it is necessary to correctly understand and insist the studentcentered teaching, so that English listening teaching can really focus on students' learning and development. That is to say, before the next class, teachers need to give the teaching points in advance; students should make good preparation and collect relevant materials before class. With the help of teachers, the students can actively find, ask and solve problems. Teacher could change the situation of students' passive role in the traditional aural English class. Furthermore, teachers should encourage students to take part in class actively.

\section{Developing Student's Comprehensive Language Competence}

The real purpose of College English listening teaching is to communicate with foreigners easier and understand their culture. And the ultimate goal is to promote students' all-round development. However, in actual teaching, we tend to equate the purpose of English listening teaching with that of examinations, which directly leads to the fact that both teachers and students pay much attention to exams. Obviously, this method has a significant effect on improving the test results, but it has some drawbacks, such as forgetting after learning and forgetting after the test, as a result, both teachers and students feel bored and tired. In order to change the above phenomenon, teachers need to pay attention to the cultivation of students' comprehensive abilities. On the one hand, listening is the primary part of the basic skills of English (listening, speaking, reading and writing), which plays a great supporting role in the cultivation of students' English abilities and qualities. On the other hand, in English listening teaching activities, teacher could provide background knowledge and key words for students before listening, and students need to think deeply and communicate with each other. Moreover, listening materials play an important role in improving students' ability of thinking and cultivating their creativity, they usually involve local customs, politics, economy and natural scenery of different countries.

\section{CREAting Authentic ENVIRONMENTS OF AURAL ENGLISH TEACHING}

People's understanding of listening cannot be separated from a certain linguistic environment, which can not only provide some necessary additional information to listeners, but also make them feel the conversation atmosphere of the speakers. Language environment is much more important than the conversation content to some extent. Therefore, it is important to build an authentic, participatory and active listening teaching environment and cultivate students' understanding of listening in different environments.

\section{A. Authenticity}

As we know, English listening teaching needs much more authenticity of teaching environment than speaking, reading, and writing [2]. For example, the same word or sentence, used in pleasant conversation between friends and the heated debate between the court, the actual meaning may be totally different, Without a good grasp of the conversational environment, it is difficult to understand the true meaning of the listening materials. At present, the college English listening teaching is generally based on audio classroom or even ordinary classrooms, most of the available tools are mainly audio and video equipment. In addition to the limitations of listening materials, the teaching environment of English listening is very poor, which limits students' understanding of listening materials and reduces the effect of listening teaching. Therefore, it is necessary to create an authentic teaching environment and improve the effectiveness of listening teaching. In particular, the so-called authentic English listening teaching environment in this paper does not refer to the degree of fidelity of the environment, but refers to the presentation of environmental clues; they are normally represented by visual materials such as charts, diagrams, illustrations and so on. Students can get more information from environmental clues.

\section{B. Participation}

In many cases, English listening is not a pure aural activity. It not only requires students to grasp the contents of listening materials correctly, but also requires students to respond immediately. However, in actual English listening teaching, teachers usually attach importance to the former and ignore the latter, for instance, teachers often ask students to respond after the end of fairly long stretches of speech, instead of asking students to participate in the whole process of listening materials. Therefore, in terms of teaching effectiveness, the lack of students' in-depth participation in English listening teaching is a test of memory rather than ability cultivation, it requires that the English listening teaching environment must have the essential feature of participation; in other words, the teachers could make an effort to let the students take initiative in class. The students could take part in listening materials under the personal direction of their teacher. For example, in English listening teaching, students can imitate one or more roles, and they are required to respond to the contents of listening materials and the role they imitate, so as to stimulate students' learning initiative and improve the effect of the English listening teaching.

\section{Initiative}

The teaching environment is a complex system, it consists of many different elements. It includes the material and the spiritual aspects. Only when they work together can they achieve their goals. However, in the construction of English listening teaching environment, English teachers pay much attention to the construction of teaching places, audio equipment, textbooks and materials, meanwhile, they also neglect the construction of positive spiritual environment, such as cultural atmosphere, emotional attitudes, and values and so on. As a result, there is a strange phenomenon that so many students watch English movies with Chinese subtitles in multimedia classrooms. This phenomenon illustrates the importance of constructing an active listening teaching environment. Generally speaking, at first, the enthusiasm of teachers could be improved in listening teaching by taking some incentive measures; secondly, student's interest could be stimulated by optimizing the way of English listening assessment and improving the contents of examination; thirdly, 
building a positive teacher-student relationship and forming a teacher-student culture of mutual respect and love, so that both sides can achieve unimaginable teaching results.

\section{Diversifying the TeAching Methods of Listening}

The research indicates that the choice of teaching methods is of great significance to achieve the expected teaching objectives [3]. However, compared with other courses, some English teachers generally believe that college English listening teaching is easier than other courses. They do not attach importance to the exploration of teaching methods. Consequently, the single teaching method of listening seriously influences the efficiency of English listening teaching. Therefore, in order to improve the effectiveness of college English listening teaching, this study suggests that teachers can diversify the teaching methods of Listening from the following aspects.

\section{A. Combining Intensive and Extensive Listening}

According to the analysis of English listening materials, it can be found that some of the materials only require students to understand the main idea, while others require students to understand in detail [4]. However, in the actual teaching of English listening, some teachers often do not distinguish between them and ask students to understand and master all the materials. As a result, the contradiction between high teaching requirements and students' limitation will cause students' passivity, and reduce the effect of English listening teaching. Besides, in the process of receiving voice from human body, English listening involves information acquisition, identification, speculation, and association and so on. It is a logical thinking process. Therefore, from the above two characteristics, this paper suggests that teachers need to adopt the teaching method of combining intensive with extensive listening in College English listening teaching. The so-called intensive listening does not mean listening again and again, but teachers need to train students step by step and gradually strengthen their mastery of vocabulary, pronunciation, grammar and context in listening materials; in extensive listening, teachers need to guide students in time and train them to acquire core materials accurately and quickly. Intensive and extensive listening reflects different requirements for teachers and students.

\section{B. Integrating Listening with other Teaching Activities}

In English teaching, listening belongs to language input, it is the passive reception and understanding of information; speaking belongs to language output, it is the active transmission and release of information. Listening is the basis of speaking, and speaking is the sublimation of listening. They are closely related as an organic whole. However, the current college English listening teaching is mainly carried out by playing audio materials or teachers' words. In the whole process, students play the role of listeners, and it is very difficult to connect listening with speaking. In view of this situation, this paper argues that listening teaching should be combined with listening and speaking activities, teachers could design some meaningful speaking activities in listening class. For instance, teachers could ask students to make group presentations they prepared before listening class; the topics of presentation are related to listening materials. Practice proves that this is a good way to improve English listening and speaking ability. Besides, there are also many effective ways to improve the effect of listening teaching. Firstly, teachers can assign some interesting tasks before listening and ask students to answer after listening; secondly, teachers can combine listening materials with speaking comprehension by making students imitate a role; thirdly, teachers can ask one student to retell the contents of listening materials, this is also a good opportunity for others to practice their listening, which at the same time makes students be accustomed to varied accent.

Reading and writing activities should be also used properly in aural English Teaching. They can help students understand the contents of the materials. For example, before listening, teachers can ask students to read key words and expressions in listening material, so as to enrich vocabularies and develop reading ability. After listening, summarizing the main idea will help students understand listening materials correctly and fully.

\section{Changing Student's Passive Role}

In traditional teaching activities, students always play a passive role in class [5]. It's important to modify students' role in aural English class. Due to the particularity of English listening teaching, students are bound to occupy more time of classroom and opportunities; teachers play the role of guides in the classroom. This leads to the contradiction between students' passivity and the requirement of listening teaching; furthermore, it leads to the phenomenon that students prefer to be a recorder rather than a thinker in listening class. Therefore, teachers must resolve this contradiction if they want to improve the effectiveness of English listening teaching. For the above situations, this paper argues that teachers need to modify students' roles. That is to say, teachers can design some wellconstructed task, and change students' passive role. To sum up, teachers should encourage students to participate actively in class. For example, when they listen to some popular and interesting materials, students could give teachers some suggestions, such as the selection of listening materials, do some role-playing based on listening materials, and exchange ideas with their teachers.

\section{Selecting TeAching CONTENT Of Listening}

As is known to all, the choice of teaching content is considered as important in teaching. It is not only the basis of teachers' teaching, but also an important source of students' learning. Therefore, the selection of teaching content is directly related to the effect of teaching. We know that college English listening teaching is different from other subjects and has its own characteristics and principles. This requires teachers not to copy the selection criteria of other subjects, but to select teaching content closely according to students' actual situation, training objectives and current affairs.

\section{A. Keeping Close to Student's Ability}

Students are actually the basis and premise of all teaching activities. However, in the selection of listening teaching content, there is a phenomenon that some teachers rely too much on curriculum standards and textbooks, but neglect students' different levels. For example, some teachers just use listening materials on the textbook, they usually let students listen to the same materials and do the same exercises in 
teaching instead of considering students' different levels. If the content is too difficult, it is easy to destroy the enthusiasm of students. On the contrary, if the content is too easy, it is easy to cause students' slack. In order to solve these problems, the research indicates that the key is to stick closely to the students' ability in the selection of teaching content. Specifically speaking, firstly, different teaching content could be selected according to students' different level; secondly, teachers could integrate the teaching content, and delete the parts in the textbooks that are obviously unsuitable for students' learning. At the same time, they could increase the teaching content that meets the needs of students. For example, according to the dialogue scenes such as shopping malls, hospitals, and libraries and so on, the listening materials about dialogue are classified, so as to strengthen students' listening comprehension ability in different situations. Finally, teachers could follow the principle of moderation, and expand the content of listening teaching appropriately. That is to say, if the students' acceptance ability is good, teachers can increase the difficulty of listening teaching content appropriately. On the contrary, if the students' acceptance ability is poor, teachers can reduce the content of listening teaching.

\section{B. Keeping Close to Training Objectives}

Different majors have different training objectives, and different training objectives have different requirements for English listening teaching. For example, for engineering majors, the training objective requires a certain degree of English language foundation, so teachers should pay attention to all aspects of balanced training in English listening teaching; for foreign trade and tourism majors, the training goal requires proficient English language skills. In English listening teaching, teachers should strengthen the listening training of language communication. The training goal is an important basis for the selection of teaching content. Therefore, in order to improve the effectiveness of English listening teaching, this paper suggests that the selection of listening teaching content should be closely related to the objective of talent cultivation. On the one hand, teachers should participate in the formulation of training objectives for different majors, meanwhile, they should truly recognize the similarities and differences of different training objectives on English listening teaching requirements; on the other hand, specialty teachers should participate in the selection of English listening teaching content, so as to make the selection more appropriate.

\section{Keeping Close to the Current Affairs}

According to the relevant theories of educational psychology, it is difficult to arouse students' interest in outdated content, and current events play a very important role in improving students' academic performance, especially in English listening teaching [6]. The author ever made an experiment: three classes with the same learning foundation were selected at the same time, the teaching content of the firstclass remained unchanged, the second class increased the current affairs appropriately in the teaching content, and the third class generally focused on the current issues. A month later, the results of test showed that the learning atmosphere and academic performance of the third class are far superior to those of the first class. As shown in the following table1:
TABLE I. THE RELATIONSHIP BETWEEN CURRENT AFFAIRS AND RESULTS

\begin{tabular}{|c|c|c|c|}
\hline Class & $\begin{array}{c}\text { Teaching } \\
\text { Content }\end{array}$ & $\begin{array}{c}\text { Before } \\
\text { Experiment }\end{array}$ & $\begin{array}{c}\text { After } \\
\text { Experiment }\end{array}$ \\
\hline One & $\begin{array}{c}\text { Remaining } \\
\text { unchanged }\end{array}$ & 72 & 73 \\
\hline Two & $\begin{array}{c}\text { Increasing the } \\
\text { current affairs }\end{array}$ & 70.5 & 75 \\
\hline Three & $\begin{array}{c}\text { Focusing on the } \\
\text { current affairs }\end{array}$ & 71 & 78 \\
\hline
\end{tabular}

From this table, we can see that there is the relationship between current affairs and results. Teachers should keep close to current affairs, when they select teaching content. Specifically, the first is to choose movies that students like, such as the movies that are just on the show; the second is to choose the recent events, such as the latest archaeological discoveries; the third is to choose issues of general concern, such as disasters caused by typhoons.

In fact, there are many hot spots that conform to the above principles. Therefore, in the selection of listening teaching content, teachers should pay attention to identify and select some valuable current affairs. For example, in the teaching of English listening for tourism majors, teachers can choose the content of discovery of new species, construction of new railways, and weather forecast and so on.

\section{CONCLUSION}

Obviously, teachers have faced many problems and difficulties in College English listening teaching. Anyhow, they should try their best to solve the problems; especially they could define the functions and roles of teachers and students by changing the teaching ideas of English listening; they could improve students' enthusiasm and acquisition by constructing teaching environment of English listening; meanwhile, they could improve the quality and efficiency of English listening teaching by diversifying English listening teaching methods; furthermore, they could deepen the connotation of talent cultivation by selecting teaching content of English listening. In short, college English listening teaching is a systematic project which involves a variety of factors. As English teachers, in addition to paying special attention to teaching ideas, environment, and methods, they still have a lot of work to do. That is to say, they should make an effort to stimulate students' interest, and they still have a long way to go.

\section{REFERENCES}

[1] Brown, T. H. Douglas, "Teaching by Principles: An Interactive Approach to Language Pedagogy,” Beijing: Foreign Language Teaching and Research Press, 2000.

[2] Ya'nan Zhao and Cuiling Zhao, "Research on College Teaching Model under the Computer Environment,” Social Networking, 2019.

[3] Anjali Mahajan and Kanica Kaushal, "Impact of Innovative Pedagogical Teaching Methods on Students’ Academic Performance,” New Nigerian Journal of Clinical Research, 2017.

[4] Fang Xie, "A Study of College English Listening and Speaking Teaching on the Basis of Multimodal Theory," Studies in Literature and Language, 2015.

[5] D’Eon Marcel, “Careful and Courageous Listening,” Canadian Medical Education Journal, 2018.

[6] Ya-hsun Tsai and Chien-hung, "The Effects of Metacognition on Online Learning Interest and Continuance to Learn with MOOCs,” Computers \& Education, 2018. 